\title{
Research on Problems and Countermeasures of Chinese Accounting Information Quality from the Perspective of Internal Control
}

\author{
Xin Cheng', a \\ ${ }^{1}$ Department of Management, Concord University College Fujian Normal University, Fuzhou \\ 350117, China; \\ a794620420@qq.com
}

Keywords: Internal control, accounting information, quality problems, countermeasures.

Abstract: With the continuous development of Chinese economic construction, accounting information has become a very important resource for the enterprises. In today's society, the authenticity, timeliness and reliability of the accounting information play a vital role in the overall operation of the enterprise. Accounting information not only affects the economic profits of the company, but also the interest of the investors. This paper starts with the relationship between the internal control and accounting information quality, and analyzes the problems of Chinese accounting information quality from the perspective of internal control, and proposes specific solutions to these problems.

\section{Introduction}

With the continuous development of Chinese economy, more and more domestic enterprises pay more attention to the accounting information, for that the accounting information will greatly affect the operation and development of enterprises. However, the quality of accounting information of Chinese enterprises is poor. It not only damages the interests of the vast number of investors, but also causes the enterprises losses and even disrupts the overall development of the market. As an important factor that ensures the quality of accounting information, internal control can guarantee the authenticity, reliability and timeliness of accounting information to the great extent. Therefore, enterprises must establish an effective internal control system and strictly implement internal control to ensure the high quality level of the enterprise accounting information.

\section{The Relationship Between Internal Control and the Quality of Accounting Information}

\subsection{Definition of Internal Control}

Internal control refers to the system of the division of responsibilities which is established by enterprises in economic activities. That is, a series of control activities are carried out by the company's board of directors, management and all employees to achieve the basic goals of the company. Furthermore, the internal control of the enterprises is an activity to improve the efficiency of the business operations, to ensure that enterprises operate in accordance with the law. The accounting information is authentic and reliable to promote enterprises to achieve the strategic goals. 
It is also an effective mechanism for enterprises to improve their management level and reduce risks. The essence of internal control is the risk management. The main contents of the internal control include the control environment, risk assessment, monitoring, control activities, information and communication. The main object of internal control is the financial controller of the enterprise and relevant senior management, the audit supervisor being responsible for internal control, etc.

\subsection{Definition of Accounting Information Quality}

According to the definition of accounting information quality in ISO8402-94 "Quality Management and Quality Assurance - Terminology" promulgated by the International Organization in 1994, the quality of accounting information is the sum of the characteristics of the ability of accounting information to satisfy clear and implicit needs. Its characteristics mainly include reliability, comparability, comprehensibility, relevance, importance, and prudence. The quality characteristics of accounting information are the criteria for selecting or evaluating the accounting standards, procedures and the methods available for selection, and are the specific requirements of the financial objectives.

\subsection{The Relationship Between Internal Control and the Quality of Accounting Information}

On the one hand, the top management of the enterprises has insufficient understanding and lack of internal control. The specific performance is insufficient understanding of the importance of the internal control and the insufficient control of internal control capabilities. Insufficient accounting regulation in the enterprise, inadequate external supervision and imperfect legal system have led to serious distortion of accounting information. On the other hand, internal control is an important factor to ensure the quality of accounting information. The generation and disclosure of accounting information are closely related to the internal control of enterprises.

\section{Problems in the Quality of Accounting Information from the Perspective of Internal Control}

\subsection{Accounting Information Governance Structure Is Not Sound}

Accounting information as an important part of the business management and development is related to the company's sustainable development. Therefore, enterprises should pay attention to the improvement of accounting information governance structure. However, at present, some enterprises' managers lack the ability to manage the internal control of the enterprise, so it may affect the quality of accounting information to a large extent. On the one hand, the managers of the enterprises lack the ability and quality of the scientific management, and it is very likely that it will not be able to constrain the top management. On the other hand, the corporate executives control the operating system of accounting information. Moreover, they stand on the commanding heights of information, which is naturally form information asymmetry. If the business of the company is contrary to executives' own interests, it may be possible to seriously decline in the quality of accounting information to satisfy their own interests.

\subsection{Lack of uniqueness in enterprise internal control system}

In order to reduce the workload and not consider their own situation, many enterprises in China do not have a unique internal control system that conforms to the company's situation. As a result, the internal control system is not perfect and cannot cover the management, departments and all 
employees, the effect of internal control is greatly declined, which will inevitably affect the quality of accounting information.

\subsection{Failure to fully utilize the functions of internal audit}

Lots of managers in some enterprises does not pay enough attention to internal audit, or a misunderstanding of auditing, or although the company has set up an internal audit institution, the internal audit cannot fully and effectively exert the function for the imperfect internal audit regulation, non-standard business and low quality of staff, and coupled with the lack of necessary supervision and management, financial accounting information is under some major shareholders' control , and the generation of accounting information has serious problems. It is not surprising that the quality of accounting information is poor.

\subsection{Lack of excellent risk assessment mechanism}

In modern enterprise management, improving the quality of accounting information and optimizing the internal control ability must rely on a scientific and sound risk assessment mechanism. In terms of the establishment and operation of internal control of the enterprises, if the enterprise does not establish a sound risk assessment mechanism, it will neither be able to guarantee the legal compliance of the business management, nor can it guarantee the quality of accounting information. First of all, the internal control management of the enterprise lacks a scientific risk assessment mechanism. The enterprise manager does not combine with the company's specific conditions to construct and improve the risk assessment mechanism. The whole corporation only relies on the enterprise's rules to maintain accounting work. Therefore, it's quite difficult to improve the risk response capability. Second, the lack of the managers' abilities to identify the risks will inevitably affect the overall quality of accounting information.

\section{Countermeasures to the problem of accounting information quality from the perspective of internal control}

\subsection{Make accounting information governance structure sound}

Improve and optimize the accounting information governance structure, specifically, maintain the relevant welfare of holders of shares and control the power expansion of strong stockholders. First of all, on this basis, an accounting information organization with unified powers and responsibilities can be established to ensure that the enterprises can complete the accounting plans and comprehensively supervise and manage various economic business activities of the enterprises. Secondly, it is necessary to make all shareholders participate in the general meeting of stockholders as much as possible, while controlling and constraining the "Veto power" of strong stockholders. Finally, in the accounting work of the enterprise, the composition of the personnel should be enriched, the accounting information should be scientifically supervised, and the quality of accounting information should be guaranteed.

\subsection{Formulate an internal control system that is suitable for the actual situation of the corporation}

The enterprise shall formulate and implement an internal control system which is applicable to the corporation in accordance with the industry standards to ensure the quality of accounting information. The specific steps are as follows: (1) Refer to the process of establishing the internal 
control system of successful enterprises and the specific terms of internal control system. (2) Reasonably analyze the current situation of the corporate. (3) Invite relevant scholars and researchers to help to formulate the unique internal control system of the enterprise.

\subsection{Strengthen internal auditing}

Internal audit is a special form of internal control, which can provide constructive opinions for the improvement of internal control system, while internal audit can supervise the effectiveness of enterprise control measures. The internal audit department also needs to be responsible for the authenticity and reliability of the company's financial information. Therefore, in addition to improve the overall efficiency of the company's operations, internal audit also helps to ensure the quality of accounting information, and can help companies effectively avoid risks. Specific measures include improving the authority of internal audit and strengthening the supervision of internal audit.

\subsection{Establish an enterprise risk assessment mechanism}

In the work of enterprise accounting information, in order to ensure the quality of accounting information and enhance the overall ability of enterprises to prevent the risks, it is necessary to rely on a sound risk assessment mechanism. On the one hand, enterprises should guide employees to continuously improve their various business capabilities, to clarify their work goals, and promote the completion of corporate goals. On the other hand, companies should explore and formulate a scientific and effective risk assessment mechanism, and continuously optimize the risk assessment system in light of the industry background. At the same time, enterprises must pay attention to raising the awareness of the risk assessment of the staff, so that they can identify the risks and deal with the risks in their daily work.

\section{Conclusions}

In summary, with the continuous development of Chinese economy, Chinese accounting information has gradually become the top priority of corporations' sustainable development, and accounting information is being paid more and more attention in enterprises. From the perspective of internal control, examining the problems of the quality of corporate accounting information and adopting effective countermeasures can not only improve the overall operational efficiency of the enterprises, but also improve the quality of accounting information of enterprises, while guaranteeing the economic benefits of the enterprises and making social economy fair.

\section{References}

[1] Ge Wang. Discussion on the Internal Control of Enterprise Accounting and the Quality of Enterprise Accounting Information [J]. China Business Theory, 2017(20): 110-111.

[2] Fei Lu. Research on Accounting Information Distortion from the Perspective of Internal Control Environment [J].China Collective Economy, 2017(08):101-102.

[3] Shuting Luan. Analysis of the Quality of Accounting Information from the Perspective of Internal Control [J/OL]. China Business Theory, 2018(26):132-133.

[4] Hui Zhou. Analysis of Accounting Information Distortion[J].Administrative Assets and Finance,2018(16):54-55.

[5] Naiyu Jiang. The Definition, Causes and Governance of Accounting Information Distortion [J]. Finance and Economics (Academic Edition), 2018 (16): 109. 